\title{
A Kalman-Filter Approach to Estimating the Natural Rate of Unemployment ${ }^{*}$
}

\author{
Victor V. Claar ${ }^{1,2}$
}

\begin{abstract}
The terms "NAIRU" and "natural rate of unemployment" are not interchangeable. Further, while there is a consensus that the NAIRU represents an empirical macroeconomic relationship, little agreement exists regarding what is meant by the "natural rate of unemployment." This paper estimates the natural rate of unemployment, defined here as the unemployment rate corresponding to equilibrium in the labor market. Rather than employ a Phillips curve, the model utilizes a macroeconomic-principles-level decomposition of the unemployment rate into its cyclical and noncyclical components. We then evaluate the estimated natural rate series by examining its relationship to structural variables from the labor market.
\end{abstract}

JEL Classification: E24, C51

Key words: Natural Rate of Unemployment, NAIRU, Kalman Filter, State-Space Models, Phillips Curve

\section{Introduction}

There is much confusion and disagreement among economists concerning the definitions of the natural rate of unemployment and the NAIRU (the non-accelerating-inflation rate of unemployment). For some, these terms are interchangeable. Gordon (1997), for

* Received: 12.04.2005; accepted: 6.05.2005

1 Assistant Professor at the Department of Economics, Management, \& Accounting, Hope College, 41 Graves Place, P.O. Box 9000, Holland, MI 49422-9000, USA. Scientific affiliation: Empirical Macroeconomics, Macroeconomic Implications of Behavioral Economics. Tel: (616) 395-7579, Fax: (616)395-7490, e-mail: claar@hope.edu; personalweb site: http://www.hope.edu/academic/ economics/claar/Personal_Page.html

2 The author wishes to thank Stratford Douglas, Sudeshna Champati Bandyopadhyay, the late Marvin Dodson, the late Jon Vilasuso, and workshop participants in the economics departments at Western Michigan University and West Virginia University for helpful comments. The author especially thanks Ronald Balvers, Douglas Mitchell, Walter Labys, and two anonymous referees for insightful and valuable comments. Any remaining errors are those of the author. 
V.V. Claar: A Kalman-Filter Approach to Estimating...

example, states that the natural rate of unemployment has more recently come to be known as the NAIRU. Cross (1995) similarly states that, "the NAIRU is a synonym for the natural rate" (p. 184). Hence, for Gordon and Cross, at least, the natural rate and the NAIRU are the same thing. Ball and Mankiw (2002), while arguing that the relevance of the NAIRU concept varies depending upon a nation's prevailing monetary regime, nevertheless refer to the natural rate of unemployment as the "approximate synonym" of the NAIRU (p. 134).

Recent studies, however, have correctly indicated that the terms "NAIRU" and "natural rate of unemployment" are not interchangeable. For example, Chang (1997) holds such a view and bases it upon the notion that unemployment-inflation tradeoffs may arise in more than one way. Espinosa-Vega and Russell (1997) go further than Chang and argue that the presence of two expressions for these similar concepts was born out of the interaction of the classical and Keynesian schools and the neoclassical synthesis. Grant (2002) identifies NAIRU as an empirical macroeconomic relationship, and the natural rate as an equilibrium condition in the labor market that reflects the market's microeconomic features.

Even among those who accept the preceding distinction, there is little agreement concerning a precise definition of the natural rate itself. Rogerson (1997) offers no fewer than twelve different definitions of the natural rate. Rogerson's sources include undergraduate textbooks, graduate textbooks, journal articles, and the Handbook of Labor Economics. Clearly, no widely accepted definition of the natural rate exists. Rogerson illustrates this point by citing Solow (1986) who makes the statement, "[I]t is not clear what we are talking about when we talk about the natural rate" (p. S24).

The purpose of this paper is to estimate the natural rate of unemployment, which we define here as the unemployment rate that is observed when the labor market is in equilibrium. At this rate, unemployment consists of frictional and structural components only. Because structural variables may influence this equilibrium position over time, the natural rate need not be time invariant.

The analysis does not directly employ any form of Phillips curve in estimating the natural rate; in fact, to do so would be to estimate the NAIRU, but not necessarily the natural rate of unemployment. Instead, the model relies upon a macroeconomic-principles-level decomposition of the actual rate of unemployment into its cyclical and noncyclical components. That part of the actual unemployment rate, the part consisting of only noncyclical unemployment, is the resulting estimate of the natural rate. Due to the model's simplicity, and consistency with the U.S. economy's stylized facts, much of the model's appeal lies in its parsimony.

The analysis proceeds as follows. In the following section, we review recent literature that traces the evolution of the terms "natural rate of unemployment" and "NAIRU." Next, we present the unemployment model used to estimate of the natural rate in a 
V.V. Claar: A Kalman-Filter Approach to Estimating...

Zbornik rad. - Sveuč. u Rij., Ekon. fak., God. 23. Sv. 1 (2005), str. 1-24

manner consistent with the results of Blanchard and Quah (1989). Having articulated the model, we then summarize briefly the operation of the Kalman filter, and utilize it to obtain an estimate of the natural rate of unemployment using only a time series of actual unemployment rate data. Since the Kalman filter may be employed to obtain smoothed estimates of an unobservable series, we use the Kalman filter to estimate the time path of the natural rate in the United States over the period 1949-2002. Next, we test the validity of the estimated natural rate series by examining its relationship to several key structural variables from the labor market. Since disturbances to the natural rate are presumed to be disturbances that permanently alter frictional and structural unemployment, such an approach lends insight concerning which structural factors have a significant impact on the natural rate. Finally, we provide a few concluding comments.

\section{Evolution of the "natural rate" and "nairu" terms}

In his landmark work, Keynes (1936) seeks to explain the high levels of unemployment associated with the Great Depression. Unconvinced that classical macroeconomic models can account for the phenomenon of persistent unemployment, Keynes offers his own competing story. According to Keynes, if nominal wages are "sticky," then it is indeed possible for labor markets to move away from their market-clearing levels. Hence, in the presence of such nominal wage stickiness, involuntary unemployment may be observed. For Keynes, then, full employment is the level of employment at which only frictional and structural unemployment exist. In order to keep the economy at the full employment level, Keynes advocates the use of fiscal policy.

As Keynes indicates, there is no reason to think that there must necessarily be zero unemployment at the full employment level. However, economists disagree considerably concerning what level of unemployment constitutes full employment. Such disagreement takes form along both theoretical and empirical lines; theorists want to know how to model full employment, and empiricists want to know how to ascertain what that level is for a given economy.

Three early-and still very frequently cited-assertions of what constitutes full employment are given by Beveridge (1944), Phillips (1958), and Friedman (1968). Beveridge contends that, at full employment, the number of unemployed persons exactly equals the number of available job openings. Phillips, a New Zealand economist, examines the empirical relationship between unemployment and wage inflation in the United Kingdom over a 100-year span ending in 1957. Discovering an inverse relationship between the two variables, Phillips concludes that full employment lies at the level corresponding to zero wage inflation. ${ }^{3}$

3 Samuelson and Solow (1960) soon thereafter demonstrate a similar relationship in U.S. data, and-further-link wage inflation with price inflation. Also note that more than 30 years prior to Phillips's publication, Irving Fisher 
V.V. Claar: A Kalman-Filter Approach to Estimating...

Zbornik rad. - Sveuč. u Rij., Ekon. fak., God. 23. Sv. 1 (2005), str. 1-24

Friedman (1968) is the first to call the full-employment unemployment rate the "natural rate of unemployment." His famous definition is as follows:

The 'natural rate of unemployment' ... is the level that would be ground out by the Walrasian system of general equilibrium equations, provided there is imbedded in them the actual structural characteristics of the labor and commodity markets, including market imperfections, stochastic variability in demands and supplies, the cost of gathering information about job vacancies and labor availabilities, the costs of mobility, and so on (Friedman, p. 8).

In articulating his definition of what constitutes full employment, Friedman simultaneously points out flaws in the definitions of Beveridge and Phillips. First, Friedman holds that there is no reason to believe that the number of job seekers is equal to the number of job vacancies at the natural rate of unemployment. Second, Friedman contends that Phillips's analysis is flawed since it focuses upon nominal, rather than real, wage inflation.

For Friedman, tradeoffs between inflation and unemployment are possible in the short run but not in the long run. And since-in Friedman's view-the short-run tradeoffs are due to unanticipated inflation, then the natural rate of unemployment is the rate of unemployment that would be observed if inflation were equal to what was expected.

While it is true that many, such as Gordon (1997), refer to the natural rate and the NAIRU interchangeably, some economists hold that they are meaningfully different, although their values may quite possibly be equal. For example, Chang (1997) holds such a view, and bases his view upon the notion that unemployment-inflation tradeoffs may arise in more than one way. Chang traces what he refers to as the natural rate back to the work of Friedman (1968), as well as Phelps (1968). In this case-the natural rate case-deviations of expected inflation from actual inflation result in movements of the economy away from full employment due to multi-period contracts; hence there may be a short-run tradeoff between inflation and unemployment. This is the view that indicates that it may be possible for policymakers to buy lower unemployment at the cost of higher inflation. Friedman certainly has made this point clear, but is equally clear that he finds such policy actions unacceptable. Under this view, the natural rate of unemployment is the unemployment rate corresponding to equilibrium in the labor market and influenced by labor market forces.

(1926) relates the rate of price inflation to one minus the unemployment rate. It was not until the publication of an historical note by Donner and McCollum (1972) that the profession became aware of Fisher's work. In 1973, the Journal of Political Economy reprinted Fisher's paper in their Lost and Found section bearing the new title, "I Discovered the Phillips Curve." 
V.V. Claar: A Kalman-Filter Approach to Estimating...

Zbornik rad. - Sveuč. u Rij., Ekon. fak., God. 23. Sv. 1 (2005), str. 1-24

manner consistent with the results of Blanchard and Quah (1989). Having articulated the model, we then summarize briefly the operation of the Kalman filter, and utilize it to obtain an estimate of the natural rate of unemployment using only a time series of actual unemployment rate data. Since the Kalman filter may be employed to obtain smoothed estimates of an unobservable series, we use the Kalman filter to estimate the time path of the natural rate in the United States over the period 1949-2002. Next, we test the validity of the estimated natural rate series by examining its relationship to several key structural variables from the labor market. Since disturbances to the natural rate are presumed to be disturbances that permanently alter frictional and structural unemployment, such an approach lends insight concerning which structural factors have a significant impact on the natural rate. Finally, we provide a few concluding comments.

\section{Evolution of the "natural rate" and "nairu" terms}

In his landmark work, Keynes (1936) seeks to explain the high levels of unemployment associated with the Great Depression. Unconvinced that classical macroeconomic models can account for the phenomenon of persistent unemployment, Keynes offers his own competing story. According to Keynes, if nominal wages are "sticky," then it is indeed possible for labor markets to move away from their market-clearing levels. Hence, in the presence of such nominal wage stickiness, involuntary unemployment may be observed. For Keynes, then, full employment is the level of employment at which only frictional and structural unemployment exist. In order to keep the economy at the full employment level, Keynes advocates the use of fiscal policy.

As Keynes indicates, there is no reason to think that there must necessarily be zero unemployment at the full employment level. However, economists disagree considerably concerning what level of unemployment constitutes full employment. Such disagreement takes form along both theoretical and empirical lines; theorists want to know how to model full employment, and empiricists want to know how to ascertain what that level is for a given economy.

Three early-and still very frequently cited-assertions of what constitutes full employment are given by Beveridge (1944), Phillips (1958), and Friedman (1968). Beveridge contends that, at full employment, the number of unemployed persons exactly equals the number of available job openings. Phillips, a New Zealand economist, examines the empirical relationship between unemployment and wage inflation in the United Kingdom over a 100-year span ending in 1957. Discovering an inverse relationship between the two variables, Phillips concludes that full employment lies at the level corresponding to zero wage inflation. ${ }^{3}$

3 Samuelson and Solow (1960) soon thereafter demonstrate a similar relationship in U.S. data, and-further-link wage inflation with price inflation. Also note that more than 30 years prior to Phillips's publication, Irving Fisher 
V.V. Claar: A Kalman-Filter Approach to Estimating...

Zbornik rad. - Sveuč. u Rij., Ekon. fak., God. 23. Sv. 1 (2005), str. 1-24

Friedman (1968) is the first to call the full-employment unemployment rate the "natural rate of unemployment." His famous definition is as follows:

The 'natural rate of unemployment' ... is the level that would be ground out by the Walrasian system of general equilibrium equations, provided there is imbedded in them the actual structural characteristics of the labor and commodity markets, including market imperfections, stochastic variability in demands and supplies, the cost of gathering information about job vacancies and labor availabilities, the costs of mobility, and so on (Friedman, p. 8).

In articulating his definition of what constitutes full employment, Friedman simultaneously points out flaws in the definitions of Beveridge and Phillips. First, Friedman holds that there is no reason to believe that the number of job seekers is equal to the number of job vacancies at the natural rate of unemployment. Second, Friedman contends that Phillips's analysis is flawed since it focuses upon nominal, rather than real, wage inflation.

For Friedman, tradeoffs between inflation and unemployment are possible in the short run but not in the long run. And since-in Friedman's view-the short-run tradeoffs are due to unanticipated inflation, then the natural rate of unemployment is the rate of unemployment that would be observed if inflation were equal to what was expected.

While it is true that many, such as Gordon (1997), refer to the natural rate and the NAIRU interchangeably, some economists hold that they are meaningfully different, although their values may quite possibly be equal. For example, Chang (1997) holds such a view, and bases his view upon the notion that unemployment-inflation tradeoffs may arise in more than one way. Chang traces what he refers to as the natural rate back to the work of Friedman (1968), as well as Phelps (1968). In this case-the natural rate case-deviations of expected inflation from actual inflation result in movements of the economy away from full employment due to multi-period contracts; hence there may be a short-run tradeoff between inflation and unemployment. This is the view that indicates that it may be possible for policymakers to buy lower unemployment at the cost of higher inflation. Friedman certainly has made this point clear, but is equally clear that he finds such policy actions unacceptable. Under this view, the natural rate of unemployment is the unemployment rate corresponding to equilibrium in the labor market and influenced by labor market forces.

(1926) relates the rate of price inflation to one minus the unemployment rate. It was not until the publication of an historical note by Donner and McCollum (1972) that the profession became aware of Fisher's work. In 1973, the Journal of Political Economy reprinted Fisher's paper in their Lost and Found section bearing the new title, "I Discovered the Phillips Curve." 
V.V. Claar: A Kalman-Filter Approach to Estimating...

Zbornik rad. - Sveuč. u Rij., Ekon. fak., God. 23. Sv. 1 (2005), str. 1-24

While this view of the natural rate suggests that any inflation/unemployment tradeoff comes about due to changes in the rate of growth of the money supply, it is also possible that low unemployment can bring about an increase in inflation regardless of the reasons for the low unemployment rate. For example, it is widely accepted that unusual labor market tightness may result in higher wages, which will create pressure for manufacturers of goods and services to raise prices. This context is the one in which Chang views the NAIRU as meaningful. In this view, the NAIRU becomes an empirical issue-unlike the more theoretical natural-rate view of Friedman and Phelps.

Chang finds the origins of the NAIRU in the work of Modigliani and Papademos (1975). In this case-the NAIRU case-low unemployment can itself generate accelerating inflation. When an economy is experiencing very low unemployment, there can be upward pressure on wages in order to attract additional workers into the labor force or to discourage current workers from seeking out better positions in other firms. Price inflation may consequently arise as firms attempt to pass along their higher labor costs to consumers. Hence, says Chang, the NAIRU is a value at which inflation is expected to neither increase nor decrease.

Espinosa-Vega and Russell (1997) go further than Chang and argue that the presence in the literature and language of economics of two expressions for very similar concepts was born out of the interaction of the classical and Keynesian schools leading to the neoclassical synthesis. Also attributing the origins of the natural rate concept to Friedman and Phelps, the authors view Modigliani and Papademos (1975) as the response of Keynesians to the events of the early-to-mid 1970s. Since active policy did not seem to be working very well in the mid 1970s, Espinosa-Vega and Russell suggest that the work of Modigliani and Papademos provided an explanation for the events of the day, but nevertheless left the door wide open to the possibility that in the right circumstances-that is, not near the NAIRU-active policy could still work well.

Hence, according to Espinosa-Vega and Russell, the NAIRU and the natural rate are the same for monetarists. The terms describe that level of unemployment that is observed when the labor market is in equilibrium. Further, it is depicted as the unemployment rate at which the long-run Phillips curve is located in a diagram of the Phillips curve.

On the other hand, the NAIRU was introduced by Keynesians as a qualification to their belief in a non-vertical Phillips curve. In light of the experience of the 1970s, Keynesians were forced to acknowledge that active policy to stimulate private demand might not always be a good idea. The NAIRU provided a way to hold onto the inflation-output tradeoff, while acknowledging that there were, in fact, limits to the role for policy activism. 
V.V. Claar: A Kalman-Filter Approach to Estimating...

Zbornik rad. - Sveuč. u Rij., Ekon. fak., God. 23. Sv. 1 (2005), str. 1-24

\section{The model}

The actual rate of unemployment, observed frequently and easily, may be viewed as the sum of two distinct components. One component, the rate of cyclical unemployment, captures the unemployment associated with changes in business conditions. The other component, which we will refer to as the natural rate component, includes frictional as well as structural unemployment. Hence, at any given time $t$, this relationship may be expressed as

$$
U_{t}=U_{t}^{N A T}+\beta_{t}
$$

where $\mathrm{U}_{t}$ is the observed actual unemployment rate, $U_{t}^{N A T}$ is the natural rate of unemployment, and $\beta_{t}$ is the rate of cyclical unemployment.

To complete the model, assumptions must be made regarding the evolution of both the natural rate and the cyclical rate. In their widely known work, ${ }^{4}$ Blanchard and Quah (1989) interpret fluctuations in unemployment and output as the result of two types of shocks: one that has a permanent impact, and one that does not. In Blanchard and Quah's view, shocks that exhibit a more permanent impact are shocks in supply: changes in technology or capital, oil disruptions, and baby booms. Such disturbances can alter the location of the long-run aggregate supply curve, simultaneously changing the level of full-employment output. Alternatively, demand shocks tend to be more ephemeral: autonomous changes in consumption or investment (Keynes's "animal spirits"), changes in foreign income, and fiscal and monetary policy changes. Moreover, demand shocks do not influence the location of the long-run aggregate supply curve and, therefore, do not influence the full-employment level of output.

Hence, we introduce two parallel disturbances to unemployment: one that has a temporary effect and one that is permanent. Again, it is helpful to regard the permanent disturbances as supply shocks that change the full-employment level of output, and the temporary disturbances as demand shocks that cannot change the full-employment level of output. Specifically, we follow King, Stock, and Watson (1995), Staiger, Stock, and Watson (1997), Gordon (1997 and 1998), Laubach (2001), and Apel and Jansson (1999a, 1999b) and assume that the natural rate of unemployment $U_{t}^{N A T}$ follows a random walk.

Further, we let the cyclical rate of unemployment $\beta_{t}$ exhibit serial correlation; Apel and Jansson (1999a, 1999b) make the same assumption. Again, as in the work of Blanchard and Quah, shocks to cyclical unemployment are thought to be from the demand side, and limited in persistence. The degree of persistence of such shocks may be influenced by the

4 Recent citations of Blanchard and Quah appear in Mocan (1999) and Galí (1999). 
V.V. Claar: A Kalman-Filter Approach to Estimating...

Zbornik rad. - Sveuč. u Rij., Ekon. fak., God. 23. Sv. 1 (2005), str. 1-24

extent of complementarity among factors of production across different sectors of the economy. Such issues are explored in Cooper and Haltiwanger (1990, 1993, and 1996).

Therefore, a given policymaker's best approximation to his stochastic environment may be characterized as:

$$
\begin{aligned}
& U_{t}=U_{t}^{N A T}+\beta_{t} \\
& U_{t}^{N A T}=U_{t-1}^{N A T}+\varepsilon_{t} \\
& \beta_{1}=\rho \beta_{t-1}+\eta_{t}
\end{aligned}
$$

where $\rho$ is between zero and one and where $\varepsilon_{t}$ and $\eta_{\tau}$ are independently distributed error terms with

$$
\varepsilon_{t} \approx N\left(0, \sigma_{\varepsilon}^{2}\right), \eta_{t} \approx N\left(0, \sigma_{\eta}^{2}\right)
$$

Observe that the use of independently distributed shocks permits the isolation of shocks to the cyclical rate of unemployment from shocks to the natural rate of unemployment. We specify the model in this fashion for two reasons. First, as stated above, we wish to follow closely the spirit of Blanchard and Quah's analysis. Second, for the decomposition of the unemployment rate that follows, it is helpful to maintain a clear dichotomy between the two sources of shocks.

Note that the specification should preclude the possibility of hysteresis in unemployment. That is, shocks to cyclical unemployment can never have an impact upon the natural rate of unemployment, and vice versa. Believers in the phenomenon of hysteresis think that cyclical unemployment can affect the natural rate of unemployment. For example-goes the hysteresis story-if a recession is unusually long in duration, then individuals who became cyclically unemployed at the onset of the recession eventually shift into structural unemployment as their human capital depreciates during the recessionary period. Hence, an individual who was laid off at the beginning of the recession may not be recalled to work even after the period of recovery is over; she has become structurally unemployed, and her unemployment is now appropriately captured in the natural rate of unemployment, rather than the cyclical rate.

\section{The kalman filter approach}

\subsection{State-Space Representation}

The model given in the preceding section is a form of unobservable components model; a policymaker observes the actual unemployment rate $U_{t}$ which consists of an unobserved natural rate component $U_{t}^{N A T}$ plus a cyclical rate component $\beta_{t}$. Such unobservable components models are especially amenable to representation via the 
V.V. Claar: A Kalman-Filter Approach to Estimating...

Kalman filter. Harvey $(1989,1993)$ deals with the application of the Kalman filter to an unobservable components context.

In the context of the model given in (1)-(3), the Kalman filter provides an optimal updating scheme for the unobservable natural rate of unemployment $U_{t}^{N A T}$ based upon observations of the actual rate of unemployment $U_{t}$ as they sequentially become available. Using Harvey's (1989) notation, the system given in (1)-(3) may be equivalently expressed in the following state-space representation:

$$
U_{t}=Z \alpha_{t}, t=1, \ldots, T
$$

where is the $2 \times 1$ vector of the state variables $U_{t}^{N A T}$ and $\beta_{t}$. $Z$ is a fixed $1 \times 2$ vector that, in the current context, contains ones for its elements. This equation, the measurement equation, relates the state variables to the observable variable $U$.

The other expression in the state-space setup is the transition equation, which indicates the evolution of the underlying state variables over time. Here the transition equation is

$$
\alpha_{t}=T \alpha_{t-1}+R \gamma_{t}
$$

where

$$
T=\left(\begin{array}{ll}
1 & 0 \\
0 & \rho
\end{array}\right), \gamma_{t}=\left(\varepsilon_{t}, \eta_{t}\right)^{\prime},
$$

$R$ is a $2 \times 2$ identity matrix, and $\varepsilon$ and $\eta$ are independently distributed error terms with

$$
\varepsilon_{t} \approx N\left(0, \sigma_{\varepsilon}^{2}\right), \eta_{t} \approx N\left(0, \sigma_{\eta}^{2}\right)
$$

Note that equation (1) does not include an additional term that might be construed as either an irregular component or as a measurement error component. We specify the model in this manner for two reasons. First, despite some popular criticism, the unemployment rate is measured reasonably well and, more importantly, is measured in the same manner every period. Second, adding an additional term to the unemployment rate equation would exacerbate the problem of distilling the natural rate of unemployment from the single unemployment rate series by introducing a third source of fluctuation in the unemployment rate. While extraction of a natural rate would still be possible within the context of such a model, the consequential informational demands placed upon the single unemployment rate series under such an approach seem unreasonable.

Under the conditions described above, the Kalman filter yields optimal predictions and updates of the state variables. More specifically, the Kalman filter provides the minimum mean square estimator (MMSE) of the vector of state variables. 
V.V. Claar: A Kalman-Filter Approach to Estimating...

Zbornik rad. - Sveuč. u Rij., Ekon. fak., God. 23. Sv. 1 (2005), str. 1-24

\subsection{Problems of Estimation}

If both processes in equations (2) and (3) were stationary, then the model could be initialized by the unconditional mean and variance matrix of the state vector. However, since the natural rate is assumed to evolve as a random walk and is therefore nonstationary, initialization of the Kalman filter becomes considerably more difficult. Harvey (1993) outlines two traditional approaches to this problem. In the first, the initial value of the nonstationary state variable is assumed to be fixed, but unknown. Hence, the unknown value for the natural rate in the initial state vector $\alpha_{0}$ must be estimated as though it is an unknown parameter in the model. Rosenberg (1973) and de Jong (1988) illustrate this approach.

In the second approach, the initial value of the nonstationary state variable is presumed to be random. Hence a diffuse prior for the distribution is assumed. Under this assumption, an initial value is, in effect, estimated by analyzing the first few observations; this approach is similar in flavor to recursive least squares. Harvey (1993) indicates the superiority of this approach over the method of estimating the initial value of the state variable.

Until quite recently, the use of a diffuse prior was considered by most econometricians to be the best available approach, even though many recognized that this technique could give rise to numerical instability. In order to address this possibility, several econometricians have proposed alternative procedures to this solution. Ansley and Kohn (1985), de Jong (1991), and Gómez and Maravall (1994) each construct algorithms in an attempt to deal with the potential for numerical instability when using a diffuse prior to initialize the Kalman filter.

Even though such algorithms offer theoretical improvements over the use of a diffuse prior, they have been criticized as difficult to deal with in practice, tedious to prove, and impossible to implement using existing software. Hence Koopman, Shephard, and Doornik (1998) advocate the diffuse prior approach. Therefore, we utilize that approach here. Note that a limitation of this method is that the first $m$ predictions and prediction errors should not be regarded as optimal, where $m$ is the number of state variables.

In the Kalman filtering process, the updating and prediction equations give the MMSE estimator of any vector of state variables in a state space model that satisfies the conditions given above. Often, one or more of the parameters in a state space model are unknown. In the current model $\rho, \sigma_{\varepsilon}^{2}$ and $\sigma_{\eta}^{2}$ are such parameters. While much of the theoretical literature assumes that the variance-covariance matrices are known, this is rarely the case in practical applications. In these instances, two approaches may be followed. In the first, a practitioner can assume reasonable values for the unknown parameters and engage in sensitivity analysis-see, for example, Lawson (1980). In the alternative, the parameters may be estimated, which is the approach followed here. 
V.V. Claar: A Kalman-Filter Approach to Estimating...

Zbornik rad. - Sveuč. u Rij., Ekon. fak., God. 23. Sv. 1 (2005), str. 1-24

\subsection{Empirical Model Estimation}

The series of data that we use in order to estimate the natural rate of unemployment via the Kalman filter is the civilian unemployment rate taken from the U.S. Bureau of Labor Statistics's Current Population Survey. The data are annual, ranging from 1947 to 2002.

Given the discussion in the preceding section, the only remaining decision to be made is which starting value of $\rho$ to use. Hence, we investigate the sensitivity of the analysis to alternative starting values of $\rho$. Blanchard and Quah (1989) estimate that temporary disturbances to unemployment peak after two to four quarters and completely die out after three to five years. Hence, we try a broad variety of starting values for $\rho$ that are consistent with a business cycle half-life ranging from 6 months to three and one-half years. Results are presented in Table 1. Note that the evaluative criterion is the log of the likelihood function, since the Kalman filter generates the MMSE of the state variables conditional upon the starting values.

As the results in Table 1 indicate, estimates of the actual value of $\rho$ and of the natural rate of unemployment in 2002 are not sensitive over different starting values of $\rho$. In fact, the results begin to change only as the corresponding beginning half-life of a business cycle is set close to three and one-half years-a value which does not accord well with the findings of Blanchard and Quah. Since the results are not sensitive over the range of reasonable starting values of $\rho$, we select the starting value of $\rho$ that yields the greatest value of the log likelihood function, 0.25 . Under that assumption, the natural rate in 2002 is estimated to be $5.71 \%$. Note that nearly identical estimated values of the natural rate would be obtained even if the starting value of $\rho$ were set to be as large as 0.4 , and would only change to $5.68 \%$ if the starting value of $\rho$ were set as large as 0.58 , corresponding to a business cycle half-life of about 15 months. Therefore, both the estimated value of the natural rate and the estimated value of $\rho$ appear to be quite robust to alternative starting values of $\rho$. Observe that the final estimated value of $\rho$ is 0.76 , corresponding to a business cycle half-life of two and one-half years, which is certainly in line with the work of Blanchard and Quah.

Recall that the values of the unknown parameters $\sigma_{\varepsilon}^{2}$ and $\sigma_{\eta}^{2}$ simultaneously estimated during the maximum likelihood process. Also recall that represents the variance of shocks (presumably supply shocks) to the natural rate and that $\sigma_{\eta}^{2}$ represents the variance of disturbances (presumably demand shocks) to the cyclical rate of unemployment. Economic intuition indicates that the variance of demand disturbances should be fairly large relative to that of supply disturbances. The results here are consistent with such intuition. The values of $\sigma_{\varepsilon}^{2}$ and $\sigma_{\eta}^{2}$ that, along with $\rho$, maximize the value of the likelihood function are $\sigma_{\varepsilon}^{2}=0.03$ and $\sigma_{\eta}^{2}=0.95$.

While the Kalman filter is indeed useful in providing an optimal updating scheme for the unobservable natural rate of unemployment, the Kalman filter can also be 
V.V. Claar: A Kalman-Filter Approach to Estimating...

Zbornik rad. - Sveuč. u Rij., Ekon. fak., God. 23. Sv. 1 (2005), str. 1-24

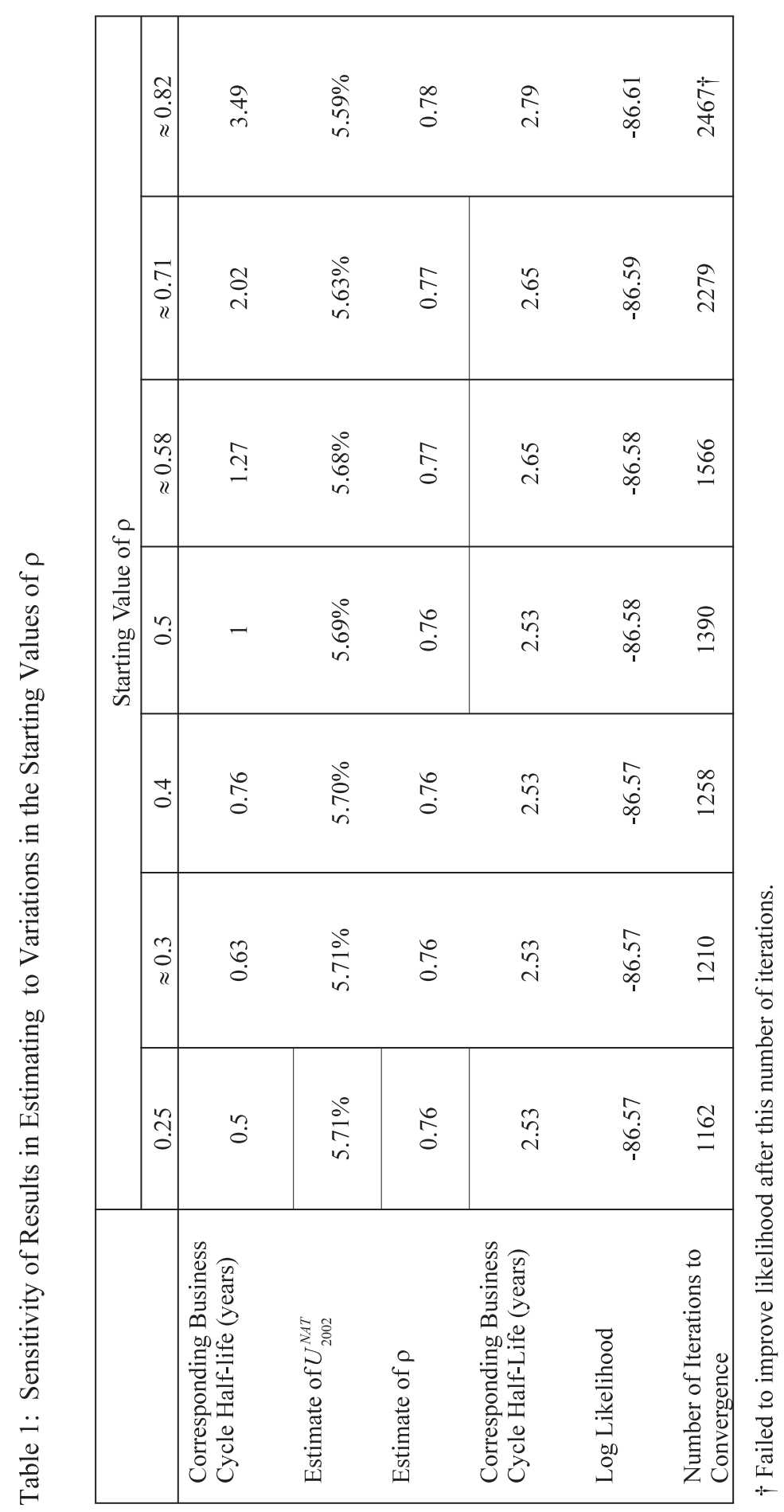


V.V. Claar: A Kalman-Filter Approach to Estimating...

Zbornik rad. - Sveuč. u Rij., Ekon. fak., God. 23. Sv. 1 (2005), str. 1-24

used to produce smoothed estimates of an unobservable series. Since more information is available at time $T$ than there was when each initial estimate of the state vector was made as new observations became sequentially available, an agent-in light of all information available at time $T$-can form revised estimates of the values of each unobservable component at each earlier time period. The solution consists of a set of recursive equations and involves working backwards from time $T$; the resulting series of the estimated unobserved components are referred to as smoothed estimates.

Figure 1 depicts the time series of actual unemployment, the original evolving point estimates of the natural rate, and the smoothed estimates of the time series of the natural rate of unemployment from 1949 to 2002. Complete smoothed results are given in Table 2. Inspection of the resulting series indicates that the natural rate ranged from as high as $5.88 \%$ in $1982-83$ to as low as $5.05 \%$ in 1951 . Further observe that the highest estimated natural rate of $5.88 \%$ in $1982-83$ closely corresponds to the highest level of unemployment in the period, $9.7 \%$ in 1982 . Also of note are the years during which the analysis indicates that the unemployment rate lay below the natural rate of unemployment. These periods occur in 1951-53, 1955-57, 1964-70, 1973-4, 1988-90, and 1995-2001.

Figure 1: Smoothed and Unsmoothed Point Estimates of the Natural Rate of Unemployment in the United States, 1949-2002

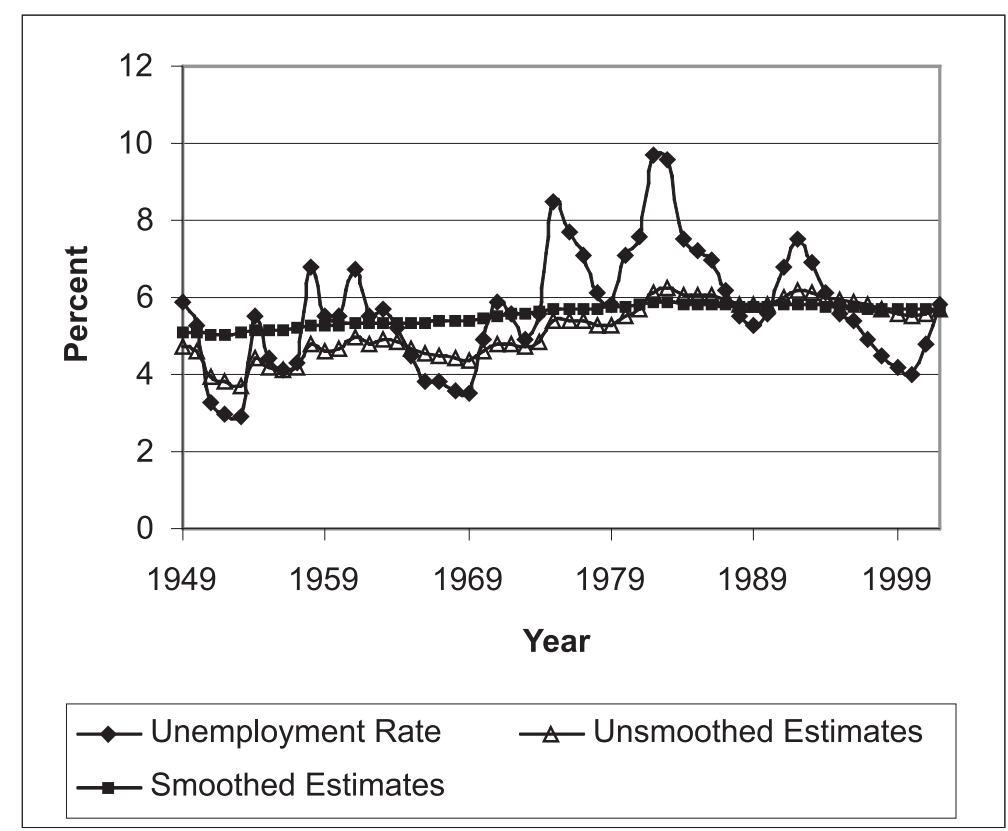


V.V. Claar: A Kalman-Filter Approach to Estimating... Zbornik rad. - Sveuč. u Rij., Ekon. fak., God. 23. Sv. 1 (2005), str. 1-24

Figure 2: The Unemployment Rate and the Smoothed Estimates of the Natural Rate and Cyclical Rate in the United States, 1949-2002

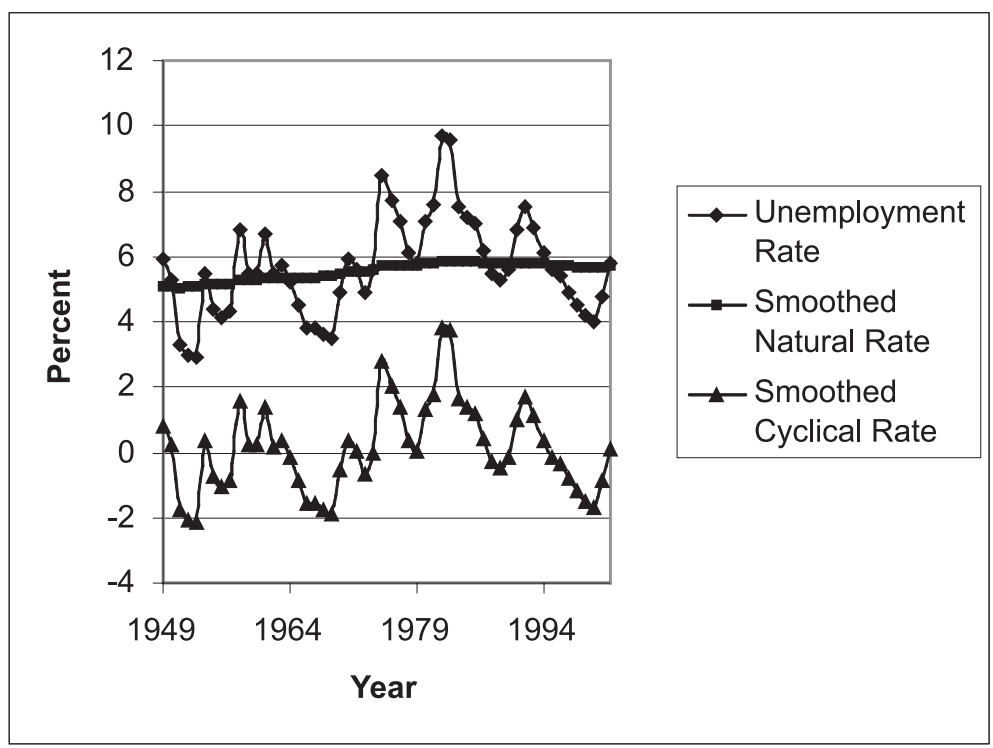

Figure 2 depicts the unemployment rate series together with the estimated series of its underlying components. As expected from the estimated values of the variances of the shock terms, most fluctuations in the unemployment rate over time are ascribed to cyclical fluctuations rather than to changes corresponding to a shift in the natural rate of unemployment. In fact, the estimated natural rate appears fairly stable over the period. The analysis indicates that the natural rate was near 5 percent at the beginning of the period, rose to nearly 6 percent during the early 1980s, and fell thereafter to its 2002 level of approximately $5.71 \%$.

The resulting series appears broadly consistent with the language of Friedman (1968, p.8) in defining the evolving natural rate. Recall that Friedman describes the natural rate of unemployment as being "ground out" by the Walrasian general equilibrium system.

Similarly, the series accords well with the "smoothness prior" articulated by Gordon (1997, p. 22): that the natural rate may "move around as much as it likes," but that sharp short-run movements must be purged. In our model, the natural rate is defined as a random walk, so it certainly is free to "move around as much as it likes." Nevertheless, the resulting smoothed estimates also suggest a rate of unemployment that evolves slowly over time, with no quick jerks in the series from one period to another.

Of course, because the natural rate estimated here indeed exhibits some movement over the span of the data, it is legitimate to ask whether the natural rate has been 
V.V. Claar: A Kalman-Filter Approach to Estimating...

Zbornik rad. - Sveuč. u Rij., Ekon. fak., God. 23. Sv. 1 (2005), str. 1-24

purged completely of all cyclical variation. Recall that the model, by construction, should preclude the possibility of hysteresis. Shocks to cyclical unemployment cannot spillover onto the evolving natural rate of unemployment. Hence, should there remain any variation in the estimated natural rate that appears related to the business cycle, this could certainly be interpreted as evidence of hysteresis. That is, since the model should preclude the possibility of spillovers of cyclical shocks onto movements of the natural rate, then remaining cyclical movements in the natural rate might be interpreted as empirical evidence of hysteresis.

To test for this possibility, we calculate a simple correlation coefficient between the smoothed natural rate series and the smoothed cyclical rate series. If fluctuations in the estimated natural rate prove orthogonal to changes in the estimated cyclical rate, then no hysteresis is present. If, alternatively, the two series are positively correlated, this result could be interpreted evidence of hysteresis. Since the simple correlation coefficient between the two series over the period 1949-2002 is 0.486, we find a significant correlation between the estimated natural rate series and its smoothed cyclical rate counterpart, where $\alpha=0.01$. Therefore, even though the model-by construction-should preclude the possibility of hysteresis, we nevertheless find evidence of a positive correlation between cyclical variations in the unemployment rate and fluctuations in the estimated natural rate of unemployment. Hence, we cannot rule out hysteresis as an empirical possibility.

In the remainder of the paper, we evaluate the estimated natural rate series by examining how well it accords with key structural variables from the labor market. If structural changes explain well the movements in our estimated natural rate series, then the Kalman filter provides a simple, parsimonious way to estimate a sensible series for the natural rate using only one series of data. 
V.V. Claar: A Kalman-Filter Approach to Estimating...

Zbornik rad. - Sveuč. u Rij., Ekon. fak., God. 23. Sv. 1 (2005), str. 1-24

Table 2: Actual Unemployment Rates and Smoothed Natural Rate Estimates, 1949-2002

\begin{tabular}{|c|c|c|c|}
\hline \multicolumn{4}{|c|}{ Smoothed Estimates } \\
\hline Year & Unemployment Rate & Natural Rate & Cyclical Rate \\
\hline 1949 & $5.9 \%$ & $5.09 \%$ & $0.81 \%$ \\
\hline 1950 & 5.3 & 5.09 & 0.21 \\
\hline 1951 & 3.3 & 5.05 & -1.75 \\
\hline 1952 & 3.0 & 5.06 & -2.06 \\
\hline 1953 & 2.9 & 5.07 & -2.17 \\
\hline 1954 & 5.5 & 5.15 & 0.35 \\
\hline 1955 & 4.4 & 5.14 & -0.74 \\
\hline 1956 & 4.1 & 5.16 & -1.06 \\
\hline 1957 & 4.3 & 5.18 & -0.88 \\
\hline 1958 & 6.8 & 5.26 & 1.54 \\
\hline 1959 & 5.5 & 5.25 & 0.25 \\
\hline 1960 & 5.5 & 5.28 & 0.22 \\
\hline 1961 & 6.7 & 5.32 & 1.38 \\
\hline 1962 & 5.5 & 5.31 & 0.19 \\
\hline 1963 & 5.7 & 5.34 & 0.36 \\
\hline 1964 & 5.2 & 5.34 & -0.14 \\
\hline 1965 & 4.5 & 5.34 & -0.84 \\
\hline 1966 & 3.8 & 5.35 & -1.55 \\
\hline 1967 & 3.8 & 5.37 & -1.57 \\
\hline 1968 & 3.6 & 5.39 & -1.79 \\
\hline 1969 & 3.5 & 5.41 & -1.91 \\
\hline 1970 & 4.9 & 5.47 & -0.57 \\
\hline 1971 & 5.9 & 5.52 & 0.37 \\
\hline 1972 & 5.6 & 5.55 & 0.05 \\
\hline 1973 & 4.9 & 5.56 & -0.66 \\
\hline 1974 & 5.6 & 5.61 & -0.01 \\
\hline 1975 & 8.5 & 5.70 & 2.80 \\
\hline 1976 & $7.7 \%$ & $5.71 \%$ & $1.99 \%$ \\
\hline 1977 & 7.1 & 5.72 & 1.38 \\
\hline 1978 & 6.1 & 5.72 & 0.38 \\
\hline 1979 & 5.8 & 5.74 & 0.06 \\
\hline 1980 & 7.1 & 5.79 & 1.31 \\
\hline 1981 & 7.6 & 5.81 & 1.79 \\
\hline 1982 & 9.7 & 5.88 & 3.82 \\
\hline 1983 & 9.6 & 5.88 & 3.72 \\
\hline 1984 & 7.5 & 5.84 & 1.66 \\
\hline
\end{tabular}


V.V. Claar: A Kalman-Filter Approach to Estimating...

Zbornik rad. - Sveuč. u Rij., Ekon. fak., God. 23. Sv. 1 (2005), str. 1-24

\begin{tabular}{|l|l|l|l|}
\hline 1985 & 7.2 & 5.83 & 1.36 \\
1986 & 7.0 & 5.83 & 1.17 \\
1987 & 6.2 & 5.80 & 0.40 \\
1988 & 5.5 & 5.78 & -0.28 \\
1989 & 5.3 & 5.77 & -0.47 \\
1990 & 5.6 & 5.78 & -0.18 \\
1991 & 6.8 & 5.80 & 1.00 \\
1992 & 7.5 & 5.81 & 1.69 \\
1993 & 6.9 & 5.79 & 1.11 \\
1994 & 6.1 & 5.76 & 0.34 \\
1995 & 5.6 & 5.74 & -0.14 \\
1996 & 5.4 & 5.73 & -0.33 \\
1997 & 4.9 & 5.71 & -0.81 \\
1998 & 4.5 & 5.69 & -1.19 \\
1999 & 4.2 & 5.68 & -1.48 \\
2000 & 4.0 & 5.67 & -1.67 \\
2001 & 4.8 & 5.69 & -0.89 \\
2002 & 5.8 & 5.71 & 0.09 \\
\hline
\end{tabular}

Table 3: Regression of the Estimated Natural Rate Series on Structural Variables for the United States Economy, 1950-1997

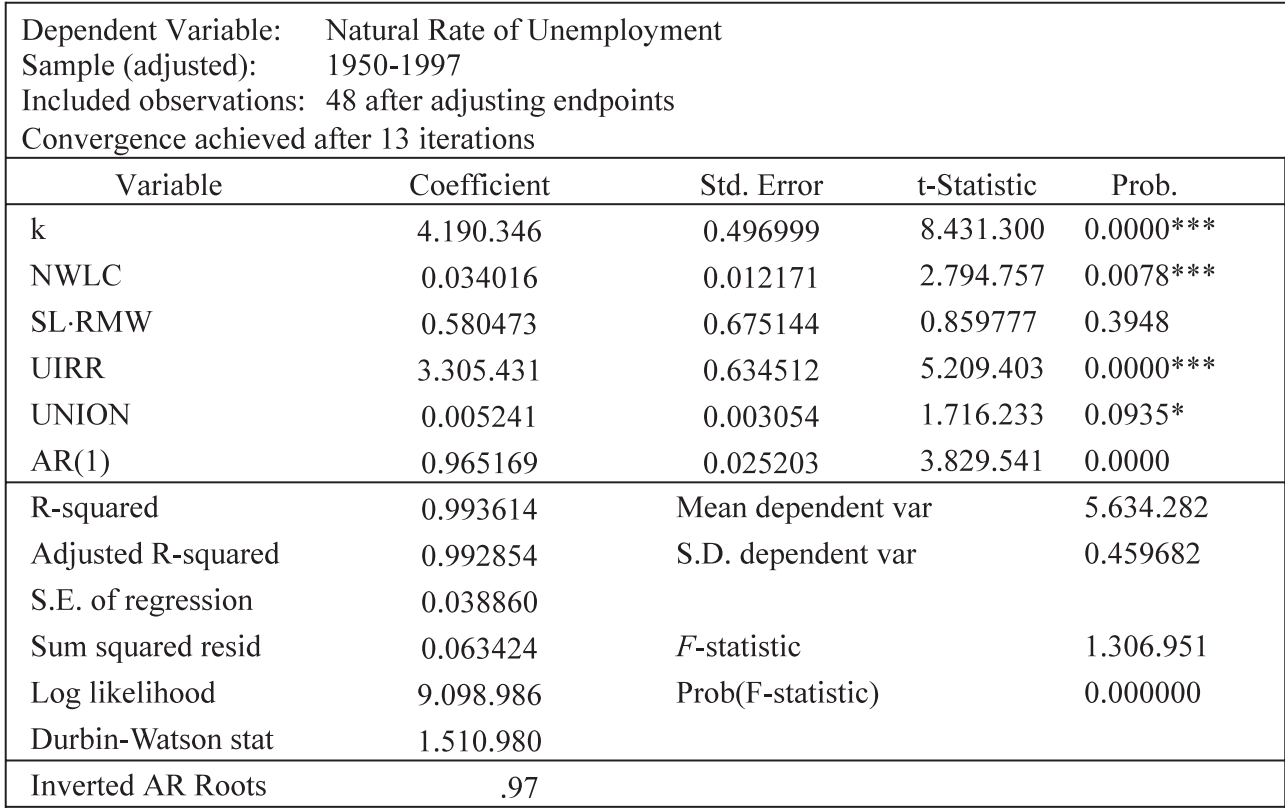

$*, * *$, and $* * *$ indicate significance at the $?=0.10,0.05$, and 0.01 levels, respectively. 
V.V. Claar: A Kalman-Filter Approach to Estimating... Zbornik rad. - Sveuč. u Rij., Ekon. fak., God. 23. Sv. 1 (2005), str. 1-24

\section{Structural variables and the estimated natural rate}

King and Morley (2003) also estimate the natural rate of unemployment without the use of a Phillips curve. In their view, a time-varying natural rate is endogenous, driven by an underlying set of structural variables. Hence, in this section, we test the validity of the estimated natural rate series from the previous section by examining its relationship to several key structural variables from the labor market. Since disturbances to the natural rate are presumed to be disturbances that permanently alter frictional and structural unemployment, such an approach can also lend insight concerning which structural factors have a significant impact on the natural rate.

Coe (1990) estimates the natural rate of unemployment in Canada for the period 1971:I to 1988:II. After testing for the significance of several structural factors in the determination of the natural rate, he ultimately selects four structural determinants for inclusion in the vector of structural variables. His choice of structural variables includes the relative minimum wage (i.e., the minimum wage as a percentage of the average commercial wage), the percentage of the labor force that is unionized, the average payroll tax rate for employers' contributions for social security and pension funds, and a proxy for the generosity of the unemployment insurance system.

Adams and Coe (1990) build upon Coe's methodology in a study that estimates the natural rate in the United States over the period 1965:I to 1988:IV. As in Coe's Canadian analysis, several alternative specifications of the regression model are tested, incorporating various combinations of possible explanatory structural variables. Adams and Coe (1990) conclude that Coe's (1990) combination of structural variables that provides the best overall fit for the Canadian economy is very robust to data from the United States.

\subsection{The Model}

Following directly Adams and Coe, we estimate the following regression equation for the natural rate of unemployment at time $t, U_{t}^{N A T}$ :

$$
U_{t}^{N A T}=k+\phi_{1} N W L C_{t}+\phi_{2} U_{I R R_{t}}+\phi_{3} S L_{t} \cdot R M W_{t}+\phi_{4} U N I O N_{t}+\tau_{t},
$$

where $N W L C$ is employers' contributions for Social Security and pension funds as a percentage of total wages and salaries, and UIRR is the unemployment insurance replacement ratio, calculated as the ratio of the average weekly unemployment insurance benefit to the average weekly wage in covered employment.

$S L$ is the share of the labor force that is young (aged 16-24), and $R M W$ is the relative minimum wage, calculated as the ratio of the minimum wage to the average hourly wage. The interaction term that is the product of the share of the labor force that is young and the relative minimum wage is included since the conventional view is that 
V.V. Claar: A Kalman-Filter Approach to Estimating...

Zbornik rad. - Sveuč. u Rij., Ekon. fak., God. 23. Sv. 1 (2005), str. 1-24

the minimum wage has the greatest impact upon younger workers. That is, changes in the minimum wage will have a greater impact upon unemployment rates the larger the share of the labor force that is young. Brown, Gilroy, and Kohen (1982) provide an extensive survey of the literature relating the minimum wage to unemployment. Kennan (1995) gives a summary and critique of more recent developments regarding the impact of minimum wage laws.

Finally, UNION represents union membership as a percentage of nonagricultural unemployment. The expected signs of the estimated coefficients on all of the structural variable terms are positive.

\subsection{Data and Estimation}

In constructing $R M W$, the ratio of the minimum wage to the average hourly earnings of production workers, average earnings data are from the Bureau of Labor Statistics. $S L$, the share of the labor force that is young, is calculated directly from Bureau of Labor Statistics's Current Population Survey data.

Unfortunately, unionization data have not been collected consistently by the same collector throughout the period. Hence, the series is constructed from several sources. Ashenfelter and Card (1986) supply data for the following years that had been missing prior to their study: $1971,1973,1975,1977$, and 1982 . The data point for 1979, and data for 1990 and 1996-97, are from the Bureau of Labor Statistics and from the Statistical Abstract of the United States, respectively. The data point for 1981 is linearly interpolated from surrounding data; all other UNION data are from Kurian (1994). ${ }^{5}$

$N W L C$ is calculated as total employee compensation less wage and salary accruals as a percentage of wage and salary accruals, the same calculation used by Adams and Coe; data are from the Survey of Current Business. UIRR is the ratio of the average weekly unemployment benefit amount to the average weekly total wage in taxable and reimbursable unemployment; data are from the Department of Labor's Employment and Training Financial Data Handbook 394, currently available through the end of 1997. Hence we estimate the model for the period ending in 1997.

Initial estimation of equation (6) suggests, according to the Durbin-Watson statistic, the presence of first-order serially correlated errors. Estimation of the model incorporating an $\mathrm{AR}(1)$ correction, using nonlinear regression techniques, ${ }^{6}$ yields the results found in Table 3.

The estimated coefficients all bear the expected sign, and the variables indicating the generosity of unemployment insurance and non-wage labor compensation are

5 Zavodny (1999) gives a recent indication of the difficulties inherent in collecting such unionization data, and the necessity of consulting a variety of sources and linearly interpolating missing points.

6 For details concerning estimation of AR models using nonlinear techniques, see Fair (1984, pp. 210-14). 
V.V. Claar: A Kalman-Filter Approach to Estimating...

Zbornik rad. - Sveuč. u Rij., Ekon. fak., God. 23. Sv. 1 (2005), str. 1-24

significant at the one percent level. The unionization variable is significant at the ten percent level.

The overall fit appears excellent. This set of structural variables explains nearly all variation in the estimated natural rate series. Hence, the Kalman filter, using only one data series, can produce a time series for the natural rate that is dramatically consistent with the structural determinants of Adams and Coe (1990). Also, the two most significant determinants of movements in the natural rate appear to be (1) employers' contributions to social security, etc., as measured by the non-wage labor compensation variable and (2) the generosity of unemployment benefits, as measured by the unemployment insurance replacement ratio variable.

\section{Conclusion}

This paper has applied the Kalman filter to an unobservable-components model of the unemployment rate in order to estimate a time series of the natural rate of unemployment in the United States. Results indicate a 2002 natural rate of unemployment of $5.71 \%$, which is less than the actual rate of unemployment measured to be $5.8 \%-$ a difference of $0.09 \%$. The resulting series suggests that the natural rate is at its lowest in 1951 when it reaches about $5.05 \%$; the highest estimated value of the natural rate occurs in 1982-83 when it rises to a value of $5.88 \%$.

There appear to be several important advantages in using the Kalman-filtering method over other estimators of the natural rate. Perhaps the main advantage of the Kalman approach as described here lies in its parsimony. As Groenewold and Hagger (2000) have pointed out, measures of the natural rate of unemployment are necessarily model dependent. Since the specification of the unemployment rate model here is quite general, it accords easily with a broad variety of macroeconomic models. Further, the approach here does not blur the concepts of the natural rate of unemployment and the NAIRU by using a Phillips curve to estimate the natural rate of unemployment. Moreover, nearly all of the movements in the resulting natural rate series can be explained by movements in key structural variables from the labor market.

An additional feature is the consideration of the Blanchard and Quah result in the formulation of the model rather than a more generic detrending approach, such as that of Watson (1986). In Watson's paper, all trend components are assumed to be random walks with drift. While such an approach might be appropriate to estimation of series such as those estimated by Watson-GNP, disposable income, and consumption expenditures-it is not appropriate to the decomposition of the natural rate into its cyclical and noncyclical components in light of the findings of Blanchard and Quah. 
V.V. Claar: A Kalman-Filter Approach to Estimating...

Zbornik rad. - Sveuč. u Rij., Ekon. fak., God. 23. Sv. 1 (2005), str. 1-24

Finally, application of the Beveridge-Nelson filter to the unemployment rate may be appropriate given Park's (1996) indication that when a pre-filtered series is integrated of order one, the resulting trend component from the Beveridge-Nelson filter will be $I(1)$ as well. While such an approach corresponds to the idea that the natural rate evolves as a random walk, there does remain controversy concerning whether the unemployment rate itself evolves as a unit root process. Application of the augmented Dickey-Fuller test suggests that the unemployment rate may indeed be a random walk, so the null of a unit root cannot be rejected. Hence, application of the Beveridge-Nelson filter may be appropriate.

\section{References}

Adams, Charles and David T. Coe. (1990), "A Systems Approach to Estimating the Natural Rate of Unemployment and Potential Output for the United States." IMF Staff Papers 37: 232-93.

Ansley, Craig F. and Robert Kohn. (1985), "Estimation, Filtering, and Smoothing in State Space Models with Incompletely Specified Initial Conditions." Annals of Statistics 13: 1286-1316.

Apel, Mikael and Per Jansson. (1999a), "System Estimates of Potential Output and the NAIRU." Empirical Economics 24: 373-88.

-. (1999b), "A Theory-Consistent System Approach for Estimating Potential Output and the NAIRU." Economics Letters 64: 271-5.

Ashenfelter, Orley and David Card. (1986), "Why Have Unemployment Rates in Canada and the United States Diverged?" Economica 53: S171-95.

Ball, Laurence and N. Gregory Mankiw. (2002), "The NAIRU in Theory and Practice." Journal of Economic Perspectives 16.4: 115-36.

Beveridge, William Henry. (1944), Full Employment in a Free Society. London: Allen \& Unwin.

Blanchard, Olivier Jean and Danny Quah. (1989), "The Dynamic Effects of Aggregate Demand and Supply Disturbances." American Economic Review 79: 655-73.

Brown, Charles, Curtis Gilroy, and Andrew Kohen. (1982), "The Effect of the Minimum Wage on Employment and Unemployment." Journal of Economic Literature 20: 487-528.

Chang, Roberto. (1997.), “Is Low Employment Inflationary?" Economic Review (Federal Reserve Bank of Atlanta) 82.1: 4-13.

Coe, David T. (1990), "Structural Determinants of the Natural Rate of Unemployment in Canada." IMF Staff Papers 37: 94-115. 
V.V. Claar: A Kalman-Filter Approach to Estimating...

Zbornik rad. - Sveuč. u Rij., Ekon. fak., God. 23. Sv. 1 (2005), str. 1-24

Cooper, Russell and John Haltiwanger. (1990), "Inventories and the Propogation of Sectoral Shocks." American Economic Review 80: 170-90.

- (1993), "The Aggregate Implications of Machine Replacement: Theory and Evidence." American Economic Review 83: 360-82.

-. (1996), "Evidence on Macroeconomic Complementarities." Review of Economics and Statistics 78: 78-93.

Cross, Rod. (1995), "Is the Natural Rate Hypothesis Consistent with Hysteresis?" in Rod Cross, ed., The Natural Rate of Unemployment: Reflections on 25 Years of the Hypothesis. Cambridge: Cambridge University Press.

de Jong, Piet. (1988), “The Likelihood for a State Space Model." Biometrika 75: 165-9.

—. (1991), "The Diffuse Kalman Filter." Annals of Statistics 19: 1073-83.

Donner, Arthur and James F. McCollum. (1972), "The Phillips Curve: An Historical Note." Economica 39: 322-4.

Espinoza-Vega, Marco A. and Steven Russell. (1997), "History and Theory of the NAIRU: A Critical Review." Economic Review (Federal Reserve Bank of Atlanta) 82.2: 4-25.

Fair, Ray C. (1984), Specification, Estimation, and Analysis of Macroeconometric Models. Cambridge, MA: Harvard University Press.

Fisher, Irving. (1926), "A Statistical Relation between Unemployment and Price Changes." International Labour Review 13: 785-92.

Friedman, Milton. (1968), “The Role of Monetary Policy." American Economic Review 58: 1-17.

Galí, Jordi. (1999), "Technology, Employment, and the Business Cycle: Do Technology Shocks Explain Aggregate Fluctuations." American Economic Review 89: 249-71.

Gómez, Víctor and Augustín Maravall. (1994), "Estimation, Prediction, and Interpolation for Nonstationary Series with the Kalman Filter." Journal of the American Statistical Association 89: 611-24.

Gordon, Robert J. (1997), "The Time-Varying NAIRU and its Implications for Economic Policy." Journal of Economic Perspectives 11.1: 11-32.

-. (1998), "Foundations of the Goldilocks Economy: Supply Shocks and the Time-Varying NAIRU." Brookings Papers on Economic Activity 2: 297-346.

Grant, Alan P. (2002), "Time-Varying Estimates of the Natural Rate of Unemployment: A Revisitation of Okun's Law." Quarterly Review of Economics and Finance 42: 95-113. 
V.V. Claar: A Kalman-Filter Approach to Estimating...

Zbornik rad. - Sveuč. u Rij., Ekon. fak., God. 23. Sv. 1 (2005), str. 1-24

Groenewold, Nicolaas and A. J. Hagger. (2000), "The Natural Rate of Unemployment in Australia: Estimates From a Structural Var." Australian Economic Papers 39: 121-37.

Harvey, Andrew C. (1989), Forecasting, Structural Time Series Models, and the Kalman Filter. Cambridge: Cambridge University Press.

-. (1993), Time Series Models. $2^{\text {nd }}$ ed. Cambridge, MA: MIT Press.

Kennan, John. (1995), "The Elusive Effects of Minimum Wages." Journal of Economic Literature 33: 1949-65.

Keynes, John Maynard. (1936), The General Theory of Employment, Interest, and Money. New York: Harcourt, Brace, and London: Macmillan.

King, Thomas B. and James Morley. (2003), "In Search of the Natural Rate of Unemployment." Working paper, Washington University in St. Louis.

King, Robert G., James H. Stock, and Mark W. Watson. (1995), “Temporal Instability of the Unemployment-Inflation Relationship." Economic Perspectives 14.3: 2-12.

Koopman, Siem Jan, Neil Shephard, and Jurgen A. Doornik. (1998), "Statistical Algorithms for Models in State Space Using SsfPack 2.2." Econometrics Journal 1: 1-55.

Kurian, George Thomas. (1994), Datapedia of the United States 1790-2000: America Year by Year. Lanham, MD: Bernan.

Laubach, Thomas. (2001), "Measuring the NAIRU: Evidence from Seven Economies." Review of Economic and Statistics 83: 218-31.

Lawson, T. (1980), "Adaptive Expectations and Uncertainty." Review of Economic Studies 47: 305-20.

Mocan, H. Naci. (1999), "Structural Unemployment, Cyclical Unemployment, and Income Inequality." Review of Economics and Statistics 81: 122-34.

Modigliani, Franco and Lucas Papademos. (1975), "Targets for Monetary Policy in the Coming Year." Brookings Papers on Economic Activity 1: 141-63.

Park, Gonyung. (1996), "The Role of Detrending Methods in a Model of Real Business Cycles." Journal of Macroeconomics 18: 479-501.

Phelps, Edmund S. (1968), "Money Wage Dynamics and Labor Market Equilibrium." Journal of Political Economy 76: 678-711.

Phillips, A. William. (1958), "The Relation between Unemployment and the Rate of Change of Money Wage Rates in the United Kingdom, 1861-1957." Economica, New Series 25: 283-99.

Rogerson, Richard. (1997), "Theory Ahead of Language in the Economics of Unemployment." Journal of Economic Perspectives 11.1: 73-92. 
V.V. Claar: A Kalman-Filter Approach to Estimating...

Zbornik rad. - Sveuč. u Rij., Ekon. fak., God. 23. Sv. 1 (2005), str. 1-24

Rosenberg, Barr. (1973), "Random Coefficients Models: The Analysis of a Cross Section of Time Series by Stochastically Convergent Parameter Regression." Annals of Economic and Social Measurement 2: 399-428.

Samuelson, Paul A. and Robert M. Solow. (1960), "Analytical Aspects of Anti-Inflation Policy." American Economic Review 50.2: 177-94.

Solow, Robert M. (1986), "Unemployment: Getting the Questions Right." Economica 53.210(S): S23-34.

Staiger, Douglas, James H. Stock, and Mark W. Watson. (1997), "The NAIRU, Unemployment and Monetary Policy." Journal of Economic Perspectives 11.1: 33-49.

Watson, Mark W. (1986), "Univariate Detrending Methods with Stochastic Trends." Journal of Monetary Economics 18: 49-75.

Zavodny, Madeline. (1999), "Unions and the Wage-Productivity Gap." Economic Review (Federal Reserve Bank of Atlanta) 84.2: 44-53. 
V.V. Claar: A Kalman-Filter Approach to Estimating...

Zbornik rad. - Sveuč. u Rij., Ekon. fak., God. 23. Sv. 1 (2005), str. 1-24

Procjena prirodne stope nezaposlenosti uz kalman-filter pristup

\author{
Victor V. Claar
}

\title{
Sažetak
}

Termini "NAIRU" $i$ "prirodna stopa nezaposlenosti" ( natural rate of unemployment), nisu istoznačnice. Dok postoji konsenzus da NAIRU predstavlja empirijski makroekonomski odnos, dotle postoje razilaženja o značenju termina "prirodna stopa nezaposlenosti". U ovome radu procjena prirodne stope nezaposlenosti određuje se odnosom stope nezaposlenosti $i$ ravnoteže na tržištu rada. Umjesto primjene Phillipsove krivulje, primjenjuje se model makroekonomskih načela u razlaganju stope nezaposlenosti na njezine cikličke i ne-cikličke sastavnice. Nakon toga, vrednuje se procjena niza prirodnih stopa nezaposlenosti na temelju ispitivanja odnosa prema strukturalnim varijablama na tržištu rada.

JEL klasifikacija: E24, C51

Ključne riječi: prirodna stopa nezaposlenosti, NAIRU, Kalman filter, model državnog prostora, Phillipsova krivulja

1 Docent na Hope College -u, 41 Graves Place, P.O. Box 9000, Holland, MI 49422-9000, SAD. Znanstveni interes: Empirijska makroekonomija, Makroekonomski implikacije behaviorističke ekonomije. Tel: (616) 395-7579, e-mail: claar@hope.edu; osobna web stranica: http://www.hope.edu/academic/economics/claar/Personal_Page.html 